\title{
UJI AKTIVITAS ANTIDEPRESAN PERASAN RIMPANG TEMULAWAK (Curcuma xanthorrhiza, Roxb) TERHADAP MENCIT PUTIH JANTAN
} (Mus musculus)

\author{
Dian Kartikasari ${ }^{*}$, Hairunisa, Emy Nadya Natasha
}

\author{
Prodi Farmasi, Akademi Farmasi Yarsi Pontianak \\ Jalan Panglima A'im No. 2 Pontianak 78232 \\ Telp. 0561-745486 fax 0561-582206 \\ *Email: dian@akfaryarsiptk.ac.id
}

\section{INTISARI}

Pencegahan dan pengobatan dengan antidepresan sintetis banyak memilki efek samping yang mempengaruhi kerja saraf pusat dan pemakaian harus dengan pengawasan dokter. Sedangkan pencegahan dan pengobatan secara tradisional relatif tidak menimbulkan efek samping, biaya murah, dan mudah didapat. Salah satu contoh obat tradisional dari bahan alami yang dapat memberikan efek antidepresi adalah rimpang temulawak. Penelitian ini bertujuan untuk mengetahui apakah rimpang temulawak memberikan efek antidepresan terhadap mencit putih jantan.

Pengujian efek antidepresan dilakukan pada mencit putih jantan (Mus musculus) dengan menggunakan metode forced swim test. Bagian tanaman yang digunakan adalah rimpang dari tanaman temulawak. Rimpang temulawak dibuat dengan perasan dan diberikan secara oral dengan konsentrasi 20\%, 40\%, dan 60\%. Kontrol negatif yang digunakan adalah Na CMC 0,5\%, sedangkan kontrol positif yang digunakan, yaitu amitriptilyn. Parameter yang diamati adalah jumlah durasi immobility time, swimming time dan climibing time (dalam satuan detik) yang dihitung dari menit ke 3-6 selama 6 menit, dan dilakukan pengujian statistik dengan nilai taraf kepercayaan $95 \%$.

Hasil penelitian menunjukan bahwa pada konsentrasi $40 \%$ perasan rimpang temulawak mempunyai nilai signifikan $(p>0.05)$ yang berarti tidak terdapat perbedaan bermakna artinya pada perasan temulawak memiliki aktivitas antidepresan yang sama dengan amitriptylin dengan nilai \% daya antidepresan pada perasan rimpang temulawak $40 \%$ yaitu $56,31 \%$ dan amitriptylin yaitu $78,78 \%$.

Kata kunci: Curcuma xanthorrhiza, Roxb, antidepresan, forced swim test

\begin{abstract}
Prevention and treatment with synthetic antidepressants has many side effects that affect the central nervous system and usage must be under the supervision of a doctor. Whereas prevention and traditional medicine relatively do not cause side effects, are inexpensive, and easy to obtain. One example of traditional medicine from natural ingredients, which can provide an antidepressant effect is ginger rhizome. This research aims to determine whether ginger rhizome have antidepressant effects on male white mice.

Antidepressant effect testing was carried out on male white mice (Mus musculus) using the forced swim test method. The part of the plant used is the rhizome of the ginger plant. Curcuma rhizome is made with juice and given orally with a concentration of $20 \%, 40 \%$, and $60 \%$. The negative control used is Na CMC 0.5\%, while the positive control used, namely amitriptilyn. The parameters observed were the duration of immobility time, swimming time and climibing time (in
\end{abstract}


seconds) which were calculated from minutes 3-6 for 6 minutes, and statistical tests were carried out with a confidence level of $95 \%$.

The results showed that at a concentration of $40 \%$ the curcuma rhizome juice had a significant value ( $p>0.05$ ) which means that there was no significant difference in antidepressant effect (\%) from the juice of temulawak $56.31 \%$ and amitriptylin $78.78 \%$

Keywords: ginger rhizome, antidepressants, the forced swim test.

*Corresponding author:

Dian Kartikasari

Prodi Farmasi, Akademi Farmasi Yarsi Pontianak

Jalan Panglima A'im No. 2 Pontianak 78232

Telp. 0561-745486 fax 0561-582206

Email: dian@akfaryarsiptk.ac.id

\section{PENDAHULUAN}

Saat ini telah tersedia obat-obat sintetis yang digunakan sebagai antidepresan diantaranya amitriptilin dan imipramin. Namun penggunaan obat-obat tersebut menimbulkan efek samping yaitu penglihatan kabur, obstipasi, mulut kering dan retensi urin (Gunawan, 2009).

Upaya untuk mencegah dan mengobati depresi telah dilakukan sejak lama. Pencegahan dan pengobatan dengan antidepresi sintesis ternyata memiliki banyak efek samping yang mempengaruhi kerja saraf pusat dan pemakaian harus dengan pengawasan dokter. Sedangkan pencegahan dan pengobatan tradisional relatif tidak menimbulkan efek samping, biaya murah, dan mudah didapat. Salah satu contoh obat tradisional dari bahan alami, yang dapat memberikan efek antidepresi adalah rimpang temulawak.

Temulawak secara historis mempunyai kegunaan tradisional dan sosial cukup luas di kalangan masyarakat Indonesia. Banyak kalangan yang mempromosikan temulawak sebagai tanaman obat khas Indonesia, yang sangat efektif untuk mengatasi gangguan liver, rematik dan lelah juga berkhasiat dalam penghilang rasa sakit, anti bakteri/jamur, antidiabetiK, antidiare, anti oksidan, antitumor, diuretik, depresi dll (Hayani, 2006). Pada uji skrining fitokimia senyawa kurkumin yang terkandung di dalam temulawak adalah 2,29\% (Hayani, 2006).

Berdasarkan uraian tersebut maka dilakukan penelitian untuk menguji efek antidepresan perasan rimpang temulawak (Curcuma xanthorrhiza, Roxb) terhadap hewan uji mencit putih jantan (Mus musculus) dengan metode forced swim test.

\section{METODE PENELITIAN}

\section{Bahan Penelitian}

Bahan-bahan yang digunakan dalam penelitian adalah aquadest, simplisia rimpang temulawak, Na CMC 0,5\%, Amitriptilin, dan mencit jantan dengan bobot 20-30 gram (sekitar 2 sampai 3 bulan) sebanyak 15 ekor.

\section{Alat Penelitian}

Alat yang digunakan dalam penelitian ini antara lain gelas kimia, gelas ukur, kandang mencit, neraca analitik (Ohaus), kain flannel, spuit $1 \mathrm{ml}$ dan jarum tumpul (sonde oral), stop watch, termometer.

\section{Jalannya Penelitian}

\section{Penyiapan sampel}

Rimpang temulawak yang diambil sebnyak 100 gram, dibersihkan dari kotoran yang menempel dan dibuang kulitnya setelah itu dicuci dengan air mengalir, dan ditiriskan.

\section{Pembuatan sampel}


Diambil rimpang temulawak yang telah dibersihkan kemudian rimpang tersebut diparut dengan menggunakan pemarut. Setelah itu disaring dengan menggunakan kain flannel kemudian dibuat dengan berbagai konsentrasi, yaitu 20\%, 40\% dan 60\%. Dimasukan ke dalam erlenmeyer, kemudian ditutup dengan menggunakan alumunium foil. Selanjutnya setiap erlenmeyer diberi tanda berdasarkan konsentrasinya.

\section{Pembuatan suspensi amitriptilin}

Sebanyak 0,1 gram Na CMC dikembangkan dengan air korpus di atas penangas air sambil diaduk hingga mengental membentuk warna transparan \pm 15 menit. Tablet amitriptilin digerus sampai halus di dalam lumpang, kemudian ditambahkan Na CMC yang sudah dikembangkan sedikit demi sedikit, digerus sampai terbentuk suspensi, kemudian dimasukkan aquades sampai 20 $\mathrm{ml}$.

\section{Pembuatan suspensi Na CMC 0,5\%}

$\mathrm{Na}$ CMC sebanyak 0,1 gram dikembangkan dengan air korpus di atas penangas air sambil diaduk hingga mengental membentuk warna transparan \pm 15 menit, ditambahkan aquades sampai $20 \mathrm{ml}$.

\section{Penyiapan hewan uji}

Disiapkan mencit putih jantan sehat dan yang telah dewasa dengan berat badan 20-30 gram. Sebelum dilakukan percobaan hewan uji dihabituasikan selama 1 sampai hari ke-7. Mencit yang digunakan untuk penelitian sebanyak 15 ekor dibagi 5 kelompok, masing-masing kelompok terdiri dari 3 ekor mencit yang ditempatkan dalam kandang terpisah.

\section{Pengujian antidepresan pada rimpang temulawak}

Pada hari terakhir habituasi, mencit diberenangkan semuanya selama 15 menit untuk pelatihan awal supaya mencit terbiasa. Mencit diberi perlakuan 1×24 jam secara oral pada hari ke 8 sampai hari ke-21 (14 hari), perlakuannya dibagi menjadi 5 kelompok seperti pada tabel I.

\section{Tabel I. Pembagian Kelompok Penelitian}

\begin{tabular}{ll}
\hline \multicolumn{1}{c}{ Kelompok } & \multicolumn{1}{c}{ Perlakuan } \\
\hline Kontrol Negatif & $\begin{array}{l}\text { Kelompok mencit yang hanya diberi perlakuan suspensi } \\
\text { Na CMC secara peroral }\end{array}$ \\
Kontrol Positif & $\begin{array}{l}\text { Kelompok mencit yang diberi perlakuan suspensi } \\
\text { amitriptilin secara peroral }\end{array}$ \\
Kelompok 1 & $\begin{array}{l}\text { Kelompok mencit yang diberi perlakuan perasan rimpang } \\
\text { temulawak 20\% secara peroral }\end{array}$ \\
Kelompok 2 & $\begin{array}{l}\text { Kelompok mencit yang diberi perlakuan perasan rimpang } \\
\text { temulawak 40\% secara peroral } \\
\text { Kelompok mencit yang diberi perlakuan perasan rimpang } \\
\text { temulawak 60\% secara peroral }\end{array}$ \\
\hline
\end{tabular}

Pada hari ke-22, 23, 24 mencit diberenangkan dalam wadah berisi air $\pm 8 \mathrm{~cm}$ dengan suhu $25^{\circ} \mathrm{C}$. Pengamatan dicatat dengan melihat gerakan immobilitytime, swimming time, climbing time setiap 6 menit, pengamatan dimulai pada menit ke 3-6.

\section{Analisis Data}

Data yang diperoleh diolah dengan menghitung \% daya antidepresan dengan rumus :

$$
\% \text { Daya Antidepresan }=100-\left(\frac{\mathrm{p}}{\mathrm{k}} \times 100\right)
$$

Keterangan :

$\mathrm{P}=$ jumlah kumulatif waktu diam mencit yang diberi perlakuan

$\mathrm{K}=$ jumlah kumulatif waktu diam mencit yang diberi kontrol negatif

Analisis statistik dilakukan menggunakan data jumlah durasi immobility, swimming, climbing pada mencit. Normalitas dan homogenitas data diuji terlebih dulu. Pada uji KolmogorofSmirnov, apabila data terdistribusi normal dan varian homogen, dilanjutkan analisis statistic 
parametric dengan Anova satu jalan (Anova One Way) dengan taraf kepercayaan 95\% dan diikuti oleh uji Tukey untuk menentukan signifikansi statistik dari berbagai kelompok.

\section{HASIL DAN PEMBAHASAN}

Rimpang temulawak dibuat dalam bentuk perasan karena pemberian perasan merupakan cara paling sederhana yang sangat sering digunakan masyarakat. Rimpang temulawak diparut menggunakan parutan setelah itu hasil parutannya disaring dan diperas dengan menggunakan kain flanel hingga diperoleh perasan temulawak.

Pada uji antidepresan metode yang digunakan adalah metode Forced Swim Tes (Tes Berenang Paksa). Pemilihan metode ini karena berhubungan langsung dengan tingkah laku hewan uji yang menyebabkan keadaan depresi pada hewan uji. Pada penelitian ini disiapkan hewan uji berupa mencit putih jantan sebanyak 15 ekor. Mencit adalah hewan yang mudah ditangani dan bersifat penakut. Mencit juga memiliki komponen darah yang dapat mewakili mamalia lainnya khususnya manusia, dan juga memiliki organ terlengkap sebagaimana mamalia. Mencit yang dipilih berkelamin jantan karena sistem imun pada mencit jantan cenderung lebih tidak dipengaruhi oleh hormon reproduksi.

Sebelum dilakukan pengujian antidepresi, mencit terlebih dahulu dihabituasikan selama tujuh hari. Tujuan habituasi adalah untuk mengkondisikan hewan uji terhadap lingkungannya agar terhindar dari stres yang dapat mempengaruhi keadaan biologisnya. Setelah hari ke-tujuh dihabituasi mencit diberenangkan selama 15 menit dengan suhu $25^{\circ} \mathrm{C}$ sebagai pelatihan awal supaya terbiasa.

Pada hari ke-7 sampai hari ke-21 mencit diberi perlakuan berupa kontrol positif, kontrol negatif, perasan temulawak 20\%, perasan temulawak $40 \%$ dan perasan temulawak $60 \%, 1 \times 24$ jam selama empat belas hari. Durasi pemberian selama empat belas hari untuk mencapai konsentrasi obat yang diinginkan di dalam darah untuk mendapatkan efek terapi pada fungsi tubuh yang mengalami gangguan. Masing-masing perlakuan diberikan secara peroral (po) karena sediaan yang dipakai adalah bentuk perasan temulawak. Di dalam perasan masih terdapat partikel-partikel yang besar dan sediaan tersebut keruh tidak jernih maka tidak mungkin diberikan secara parenteral, sedangkan pemberian obat secara parenteral sediaan harus jernih dan tidak terdapat partikelpartikel yang besar serta sediaan harus steril.

Kontrol positif yang digunakan adalah suspensi amitriptilin karena mekanisme kerja obat amitriptilin meningkatkan serotonin, norepinefrin, dan dopamin di terminal saraf. Peningkatan ketiga neurotransmitter bisa menghambat aktifitas Monoamine Oxidase Inhibitor (MAOI) di otak (Sanmukhani dkk., 2011). Pada temulawak terdapat zat kurkumin sebagai zat aktif antidepresan dengan mekanisme kerja yang dapat meningkatkan serotonin, norepinefrin, dan dopamin di terminal saraf dan juga menghambat aktifitas MAOI. Amitriptylin dipilih sebagai kontrol positif karena amitriptylin mempunyai mekanisme kerja yang sama dengan kurkumin.

Setelah hari ke-21 sampai hari ke-23 mencit dimasukkan ke dalam wadah silinder yang berisi air sampai kaki dan ekor mencit tidak menyentuh dasar wadah dan dengan suhu $25^{\circ} \mathrm{C}$. Jika suhu kurang dari $25^{\circ} \mathrm{C}$ mencit akan mengalami hipotermia yaitu kondisi tubuh yang tidak mampu untuk mengatasi tekanan suhu dingin. Setelah itu diamati mencit berenang selama 6 menit, pengamatan dimulai pada menit ke 3-6. Pada menit ke 1-3 tidak dihitung karena dianggap hanya sebagai pertahanan pada mencit, jadi pengamatan immobility time, swimming time, climbing time dimulai pada menit ke 3-6. Ketiganya harus diamati untuk membantu dalam memprediksi, kemungkinan ada pengaruh neurotransmitter yang terlibat dalam antidepresan seperti aksi kurkumin yang meningkatkan baik perilaku swimming dan climbing pada mencit (Sanmukhani dkk., 2011).

Tabel II memperlihatkan nilai $\mathrm{F}$ hitung immobility time dan swimming time $>$ dari $\mathrm{F}$ tabel, dan pada nilai signifikansi immobility time dan swimming time $(\mathrm{p}<0,05)$ ini artinya $\mathrm{H}_{0}$ ditolak dan $\mathrm{H}_{1}$ diterima artinya semua perlakuan mempunyai perbedaan yang bermakna. Pada climbing harga $\mathrm{F}$ hitung > dari $\mathrm{F}$ tabel dan pada nilai signifikansinya $(\mathrm{p}>0,05)$ ini artinya $\mathrm{H}_{0}$ diterima dan $\mathrm{H}_{1}$ ditolak artinya tidak mempunyai perbedaan yang bermakna. 
Tabel II. Aktivitas Antidepresan Perasan Temulawak dalam Immobility time, Swimming time dan Climbing time

\begin{tabular}{lcccc}
\hline \multicolumn{1}{c}{ Perlakuan } & $\begin{array}{c}\text { Immobility } \\
\text { Time }(\mathbf{s}) \\
(\mathbf{m e a n} \pm \text { SD) }\end{array}$ & $\begin{array}{c}\text { Swimming } \\
\text { Time }(\mathbf{s}) \\
(\mathbf{m e a n} \pm \text { SD) }\end{array}$ & $\begin{array}{c}\text { Climbing } \\
\text { Time }(\mathbf{s}) \\
(\mathbf{m e a n} \pm \text { SD) }\end{array}$ \\
\hline kontrol (+) & & $18,0 \pm 8,7$ & $144,7 \pm 12.3$ & $10,0 \pm 3,6$ \\
kontrol (-) & & $118,3 \pm 6,0^{*}$ & $56,7 \pm 4.5^{*}$ & $5,0 \pm 1,7$ \\
Kelompok 1(20\%) & & $60,3 \pm 10,4^{*}$ & $113,3 \pm 8.3^{*}$ & $6,7 \pm 1,5$ \\
Kelompok 2 (40\%) & & $51,7 \pm 10,8$ & $116,0 \pm 7,1^{*}$ & $12,7 \pm 3,1$ \\
Kelompok 3 (60\%) & & $51,7 \pm 16,8$ & $119,3 \pm 14,4$ & $9,3 \pm 4,9$ \\
& F h & 28,688 & 31,328 & 2,571 \\
One way ANOVA & F t & 5,96 & 5,96 & 5,96 \\
& df & 4 & 4 & 4 \\
& p & & 0,000 & 0,103 \\
\hline
\end{tabular}

Berdasarkan data tabel II, semua hasilnya dinyatakan sebagai \pm rata Standar Deviasi (SD). Sesuai dengan hasil pengujian yang dilakukan dapat dilihat bahwa kontrol positif (Amitriptilin) memiliki rata-rata immobility time paling sedikit yakni 18,0 detik dan kontrol negatif dengan ratarata immobility time paling tinggi yakni 118,3 detik serta waktu rata-rata dari perasan temulawak $20 \%$ adalah 60,3 detik, perasan temulawak $40 \%$ adalah 51,7 detik dan perasan temulawak $60 \%$ adalah 51,7 detik. Pada penelitian ini semakin besar jumlah durasi immobility yang ditunjukkan pada hasil penelitian, maka semakin rendah daya antidepresan dan begitu juga sebaliknya, semakin kecil jumlah durasi immobility semakin besar pula daya antidepresan dari perlakuan tersebut. Dilihat dari tabel II pada immobility time pada perasan temulawak $40 \%$ dan $60 \%$ nilai $\mathrm{p}>0.05$ berarti tidak mempunyai perbedan bermakna artinya pada perasan temulawak $40 \%$ dan $60 \%$ menghasilkan efek yang sama dengan kontrol positif yaitu amitriptilyn. Pada swimming time hanya terdapat pada perasan temulawak $60 \%$ yang sama dengan kontrol positif, dan pada climbing time semua perasan $20 \%, 40 \%$ dan $60 \%$ tidak mempunyai perbedaan bermakna dengan kontrol positif.

Pada tabel II dapat dilihat rata-rata immobility time \% daya antidepresan kelompok hewan uji yang diberi perasan temulawak konsentrasi $20 \%$ mempunyai daya antidepresan yang lebih rendah daripada perasan temulawak konsentrasi $40 \%$ dan 60\%. Perasan temulawak $40 \%$ dan $60 \%$ mempunyai daya antidepresan yang sama. Jadi di antara ketiga konsentrasi perasan temulawak yang efektif memiliki daya antidepresan adalah konsentrasi $40 \%$.

Tabel III. Rata-rata Daya Antidepresan

\begin{tabular}{lc}
\hline Perlakuan & $\begin{array}{c}\text { Rata-rata \% Daya } \\
\text { Antidepresan }\end{array}$ \\
\hline Kontrol (+) & $78,78 \%$ \\
Konsentrasi $20 \%$ & $48,30 \%$ \\
Konsentrasi $40 \%$ & $56,31 \%$ \\
Konsentrasi $60 \%$ & $56,05 \%$ \\
\hline
\end{tabular}

Berdasarkan tabel III terlihat rata rata daya antidepresan tertinggi adalah pada konsentrasi 40\%. Pada konsentrasi $60 \%$ malah lebih kecil daya antidepresannya dari konsentrasi $40 \%$. Peningkatan konsentrasi perasan rimpang temulawak seharusnya meningkatkan respon yang sebanding, namun pada penelitian ini dengan meningkatnya konsentrasi perasan rimpang temulawak ternyata responnya tetap, karena sudah tercapai konsentrasi yang sudah tidak dapat meningkatkan respon lagi (Bourne dan Zastrow, 2001). Hal ini sering terjadi pada obat bahan alam, karena komponen senyawa yang dikandungnya tidak tunggal melainkan terdiri dari berbagai macam senyawa kimia, yang komponen-komponennya saling bekerja sama untuk menimbulkan efek. Namun dengan peningkatan konsentrasi, jumlah senyawa kimia yang dikandung semakin 
banyak, sehingga terjadi interaksi yang merugikan yang menyebabkan penurunan efek. Rata-rata daya antidepresan dapat dilihat pada gambar 1 .

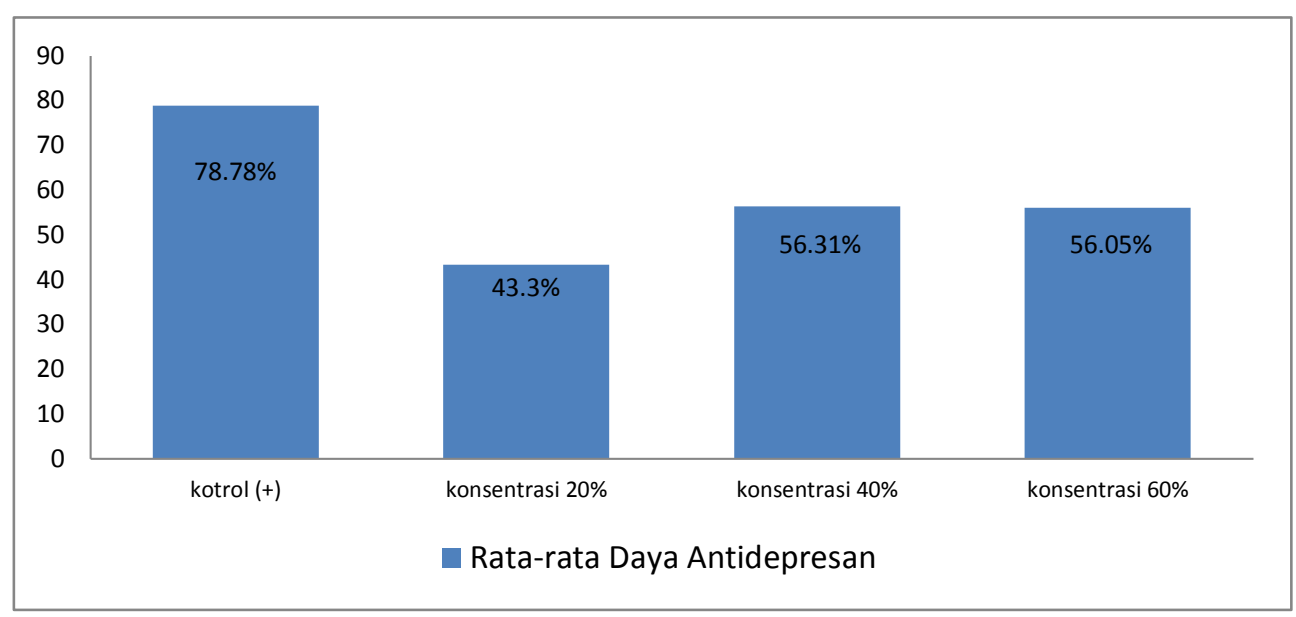

\section{Gambar 1. Rata- rata Daya Antidepresan}

Analisis statistik untuk jumlah durasi immobility, swimming dan climbing didapatkan hasil uji normalitas dengan Kolmogrov-Smirnov menunjukkan bahwa semua perlakuan terdistribusi normal $(\mathrm{P}>0,05)$, karena mempunyai nilai signifikan > 0,05 yaitu immobility 0,744, swimming 0,497 dan climbing 0,549. Sedngkan hasil analisis homogenitas varian diperoleh nilai immobility 0,220, swimming 0,221 dan climbing 0,145 artinya $\mathrm{H}_{0}$ diterima yang berarti bahwa ketiga varian adalah sama (homogen) dan dapat diterima.

\section{KESIMPULAN}

Perasan rimpang temulawak mempunyai efek antidepresan terhadap mencit putih jantan (Mus musculus), dan konsentrasi perasan rimpang temulawak $40 \%$ menghasilkan efek antidepresan yang paling efektif.

\section{UCAPAN TERIMA KASIH}

Ucapan terimakasih kami berikan kepada Akademi Farmasi Yarsi Pontianak yang telah memberikan dukungan selama penelitian berlangsung.

\section{DAFTAR PUSTAKA}

Bourne, H.R., dan Zastrow, M.Von, 2001. Drug Receptors And Pharmacodynamics in Katzung, B. G. Ed., Basic and Clinical Pharmacology. New York: Mc Graw-Hill

Gunawan, 2009.Farmakologi dan Terapi. Edisi ke-5. Jakarta. Balai Penerbit Fakultas Kedokteran UI.

Hayani, E. 2006.Analisis Kandungan Kimia Rimpang Temulawak. Bogor. Balai Penelitian Tanaman Rempah Dan Obat.

Sanmukhani J., Anovadiya A., Chandrabhanu B., Tripathi, 2011. Evaluation of Antidepressant Like Activity of Curcumin and Its Combination with Fluoxetine and Impramine: An Acute and Chronic Study, Acta Poloniae Pharmaceutica Drug Research, 68(5), 769-775 